\title{
THYROIDECTOMY-RELATED SWALLOWING DIFFICULTIES: REVIEW OF THE LITERATURE
}

\author{
Ana Đanić Hadžibegović ${ }^{1,2,3}$, Filip Hergešić ${ }^{3}$, Ema Babić ${ }^{1}$, Juraj Slipac ${ }^{1}$, Ratko Prstačić ${ }^{1,4}$ \\ ${ }^{1}$ Clinical Department for ENT and Head and Neck Surgery, Zagreb University Hospital Centre, \\ ${ }^{2}$ Faculty of Dental Medicine and Health, Josip Juraj Strossmayer University of Osijek, Croatia, \\ ${ }^{3}$ School of Medicine, Zagreb University, Croatia, \\ ${ }^{4}$ Faculty of Education and Rehabilitation Sciences University of Zagreb, Croatia
}

\begin{abstract}
SUMMARY - This study aims to provide insight into the etiology and frequency of swallowing complications that arise after thyroidectomy and to outline the available diagnostic procedures by revising the existing literature on this topic. We conducted a bibliographic search using the electronic database MEDLINE/PubMed to identify all relevant articles and 44 studies were included in the review out of a total of 218 published articles. Dysphagia after thyroid surgery is a common postoperative complication which, in the short- or long-term, significantly affects patient life quality. There is no standard diagnostic protocol for thyroidectomy-related swallowing impairment. Among the reviewed studies, 8 questionnaires and 12 instrumental diagnostic tools were used to identify swallowing difficulties related to thyroid surgery. The Swallowing Impairment Index (SIS-6) was the most-used questionnaire. Fiberoptic endoscopy is a standard diagnostic tool performed prior and after thyroid surgery, primarily to identify changes in vocal fold mobility. Although instrumental findings usually reveal non-specific alterations of swallowing; swallowing videofluoroscopy and esophageal manometry can be the most helpful tools in further management of thyroidectomy dysphagia. In patients with thyroidectomy-related swallowing difficulties and suspected laryngopharyngeal reflux, 24-hour MII$\mathrm{pH}$ metry should be performed.
\end{abstract}

Key words: thyroidectomy, swallowing disorders, dysphagia

\section{Introduction}

Thyroid surgery is the most common surgery on the endocrine glands and has become very safe with a low complication rate and a mortality rate of less than $1 \%^{1,2}$. That is the reason why the focus has shifted towards preventing postoperative morbidity and in doing so enhancing the patient quality of life (QoL).

The extent of thyroid resection as well as manipulations taken adjacently to laryngeal structures are the main factors that lead to potential complications of thyroid surgery ${ }^{3}$. While dysphonia and dysphagia caused by an injury to laryngeal nerves are a well-recognized and researched complications of thyroidecto-

Corresponding author: Ratko Prstačic, $M D, P h D$, ENT Department, University Hospital Centre Zagreb, Kišpatićeva 12, 10000 Zagreb, Croatia

E-mail: rprstacic@gmail.com my, upper aerodigestive symptoms that appear despite preservation of recurrent laryngeal nerves and the external branch of the superior laryngeal nerve have yet to be completely understood and explained ${ }^{1,4,5}$. These symptoms are usually reported by patients as generic discomfort, tightness, lumps, foreign bodies, and difficulty or pain during swallowing ${ }^{6}$, and may persist long after the surgical procedure ${ }^{7}$.

Since standard ENT evaluations had difficulty finding the exact cause that leads to the development of upper aerodigestive symptoms, they tended to be neglected by both ENT specialists and other clinicians. The rising awareness that the presence of such alterations causes stress and anxiety among patients and significantly reduces patient QoL has led to an increase in the number of studies on this functional post-thyroidectomy syndrome ${ }^{4,7,8}$. The modality of these investigations has varied significantly, from patient-report based approaches 
that rely on questionnaires assessing QoL, swallowing dysfunction, and/or presence of neck symptoms to objective instrumental diagnostic procedures performed by clinicians such as nasofiberoscopy, videofluoroscopy, or electromyography.

Still, there are many unanswered questions: how does the thyroid surgery influence swallowing, how does it affect patients QoL, and which diagnostic procedures should be included in the standard diagnostic workup of patients with thyroidectomy-related dysphagia.

\section{Aim of the study}

This study aims to provide insight into the etiology and frequency of swallowing complications that arise after thyroidectomy and to outline the available diagnostic procedures by revising the existing literature on this topic.

\section{Methods}

We conducted a bibliographic search using the MEDLINE/PubMed electronic database to identify all relevant articles until January 2020. Articles in English, Italian, and German language were included. The bibliographic search included articles with the following medical subject headings (MESH) using a search pattern: ((thyroidectomy [MeSH Terms]) OR (goiter[MeSHTerms]) OR (thyroid carcinoma[MeSH Terms])) AND ((swallowing disorder[MeSH Terms]) OR (esophageal motility disorder[MeSH Terms]) OR (sphincter, upper esophageal[MeSH Terms]) OR (dysphagia[MeSH Terms])) (Figure 1). In addition to the PubMed search, a manual search of the references cited by relevant articles given in the aforementioned search was conducted as well. This study follows the preferred Reporting Items for Systematic Reviews and Meta-Analyses (PRISMA) guidelines.

\section{Selection criteria}

Institutional review board approval and patient consent were not required due to the nature of this study. Studies we included in the revision met the following criteria: recorded clinical symptoms of postoperative dysphagia with postoperative follow-ups after a thyroid surgery with or without neck dissection, and evaluation of postoperative dysphagia either with medical equipment or questionnaires related to dysphagia, or both. Studies excluded from the analysis were: case reports or case series, review articles that did not include original data, and studies with incomplete data or description of swallowing difficulties.

\section{Studies}

This review includes papers published in journals with a peer-review policy, which observed and quantified the occurrence and characteristics of swallowing difficulty in patients undergoing thyroidectomies with or without neck dissection.

\section{Outcomes of interest}

Our primary interest in this review was to determine which diagnostic methods, questionnaires, and instrumental tools are best suited for daily clinical use to identify and quantify the extent of swallowing impairment in patients after thyroid surgery.

\section{Data screening and extraction}

The initial screening of articles indicated by the search was performed by two independent investigators. The titles and keywords were analysed, as well as the abstract of the publication when it was available. A detailed full-text analysis was independently conducted afterwards by three reviewers and data from the articles were extracted and categorized according to types of diagnostic instrumental procedures and dysphagia-related questionnaires. Any disagreement concerning data evaluation was reviewed and resolved among the three reviewers.

\section{Results}

A total of 218 published articles were retrieved from the initial search (Figure 1).

After exclusion of duplicates (0) and ineligible studies (166), 52 articles were included for further reading. After full reading, 11 studies were excluded from the review due to: irrelevance $(n=2)$, imprecise data $(n=2)$, lack of scores for dysphagia $(n=2)$, full-text articles were not accessible $(n=3)$, and being reviews of the literature (2). The PRISM Flow chart diagram of the search process is shown in Figure 2. 


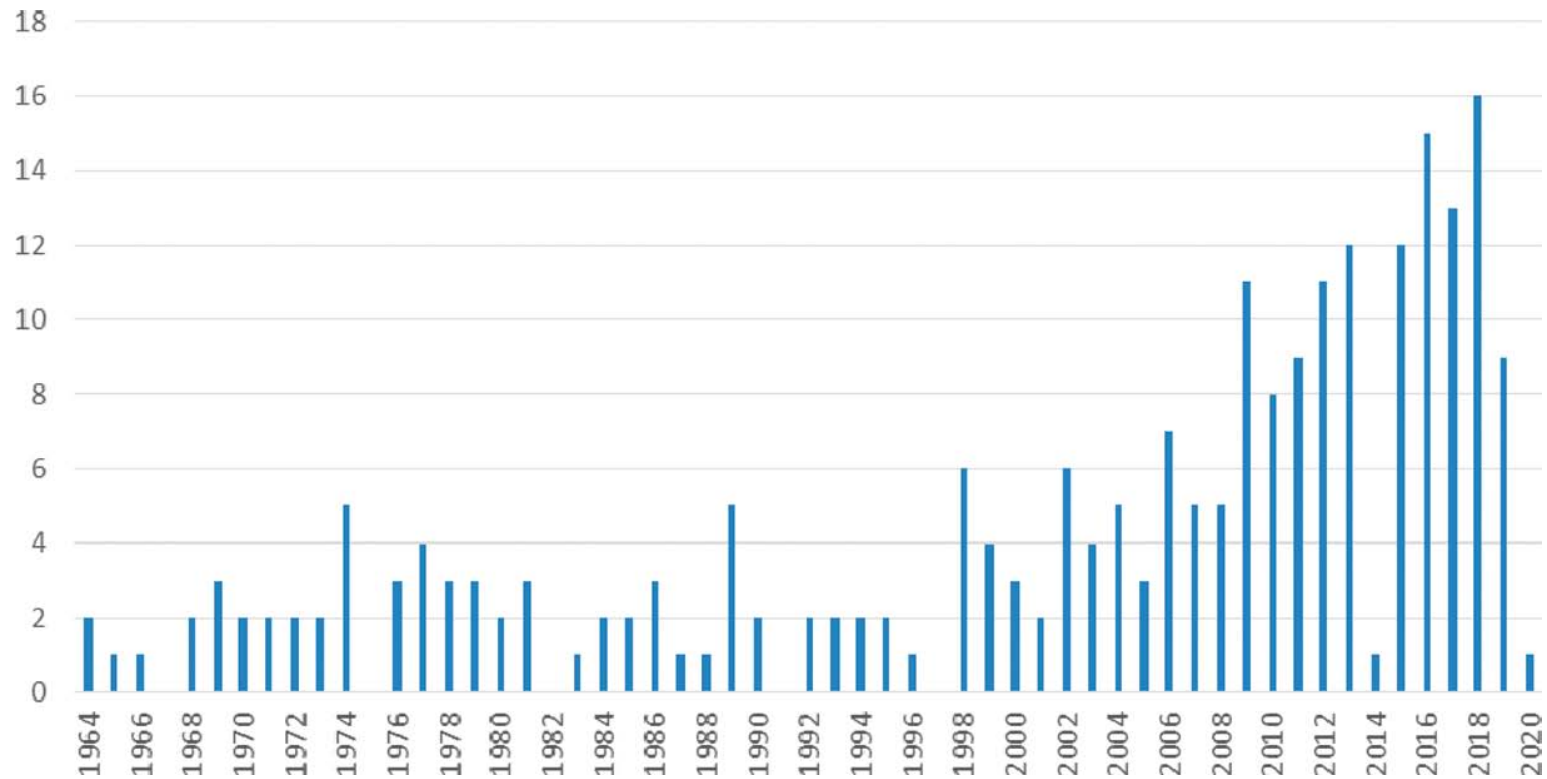

Figure 1. Number of published articles from 1964 until January 2020, from a MEDLINE/PubMed bibliographic search.

The types of studies included in the review were: 29 prospective cohort studies ${ }^{4-6,8-33}, 7$ case-control studies $^{34-39}, 3$ retrospective studies ${ }^{7,40-42}$, and 2 cross-sectional studies ${ }^{43,44}$.

\section{Etiology of post-thyroidectomy dysphagia}

Most of the authors agreed on the classification of post-thyroidectomy swallowing difficulties regarding the damage of laryngeal nerves, recurrent laryngeal nerve (RLN), and superior laryngeal nerve (SLN). The influence of RLN and SLN on swallowing is very well known and described in the current literature, and swallowing impairment related to nerve damage is often accompanied by voice changes. RNL provides motoric input for all intrinsic laryngeal muscles, except the cricopharyngeal muscle and sensory innervation for the upper esophagus ${ }^{45}$. Lesions on the RLN leads to vocal cord paresis or paralysis and incomplete glottal closure and dysfunction of the upper esophageal sphincter ${ }^{44}$. SLN innervates the cricothyroid muscle that tenses the vocal cord and provides sensitive innervation for the supraglottis and glottis. The diagnosis of SLN lesions is challenging because the clinical signs and symptoms are frequently not pronounced and patients usually complain of restricted voice loudness and pitch and rarely of cough during swallowing of liquid ${ }^{46,47}$.
Swallowing impairments after uncomplicated thyroid surgery are still not very well studied and are often under-diagnosed. In the early postoperative weeks after thyroidectomy, swallowing impairment is reported by most patients $(50-80 \%)^{48,49}$. Symptoms are often unspecific: generic discomfort, tightness, lumps, foreign bodies, and difficulty or pain during swallowing ${ }^{6}$. They are usually self-limiting, are not related to impaired nerve function, and improve spontaneously. Most of the symptoms resolved within 3 months of operation, but $20 \%$ of patients have longer-lasting dysphagia $^{49}$. Dysphagia after uncomplicated thyroidectomy can be caused by intubation, surgical procedure and manipulation, and scaring ${ }^{4,6,50}$. Current studies have shown that patients with swallowing difficulties after uncomplicated thyroidectomy have a decrease in upper esophageal sphincter (UES) pressure or UES incoordination, and several studies have found decreased laryngeal mobility and restriction of hyoid bone movements $6,9,15,20,25,51$. The degree of swallowing impairment and incidence correlated with the extent of the thyroid surgery procedure, and the more invasive the operation was, the more patients suffered from dysphagia and neck discomfort symptoms ${ }^{15,51}$. The surgical techniques may also influence swallowing. Authors who have compared conventional open thyroidectomy to robotic techniques, minimally inva- 


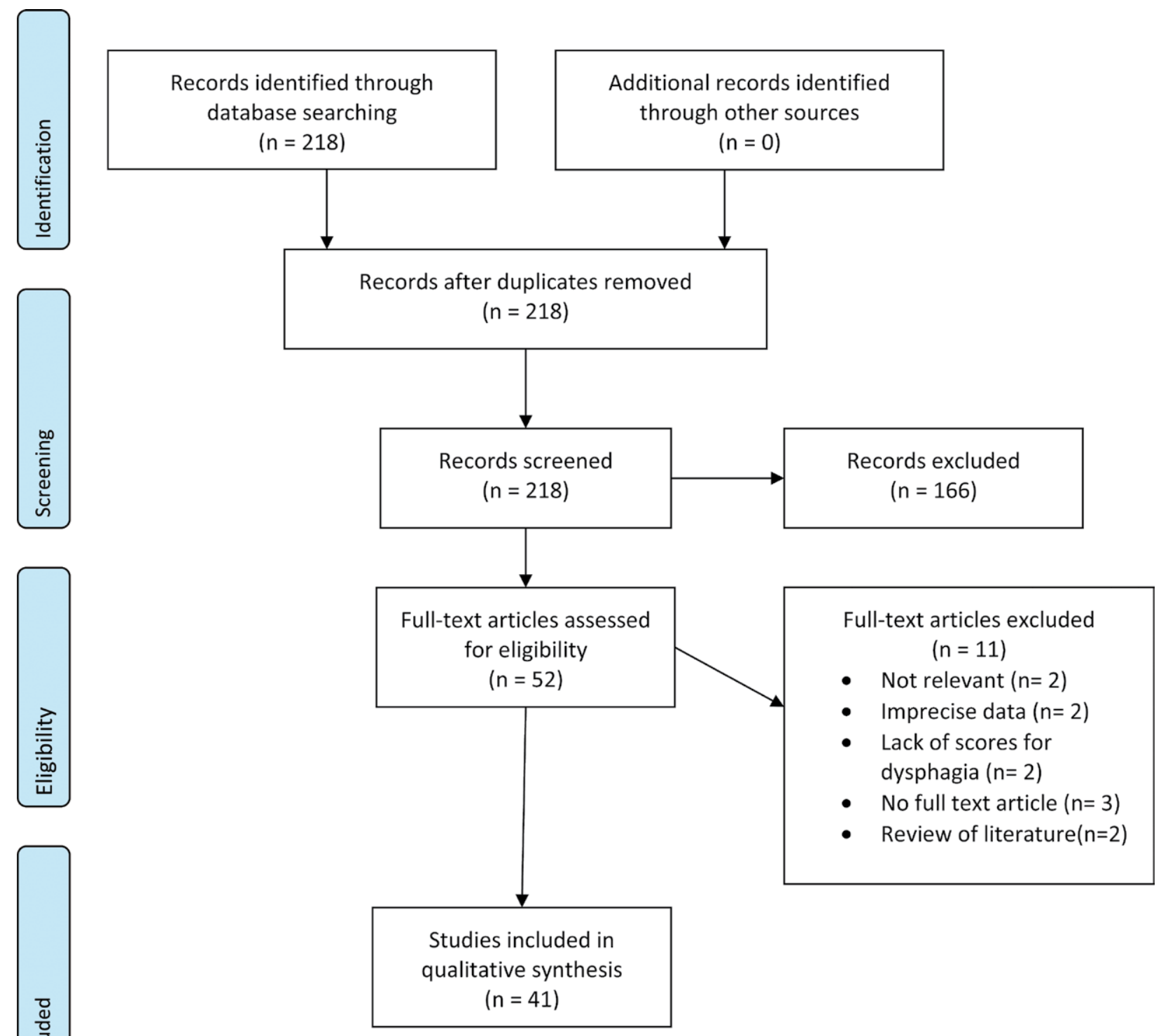

Figure 2. Study search flow chart.

sive thyroid surgery, and subfascial approach to the thyroid reported a statistically significant increase of swallowing impairments in the conventional group $^{10,11,16,33,37,38,52,53}$. Additionally, laryngopharyngeal reflux (LPR) could influence postsurgical swallowing complaints $6,13,25,54,55$.

\section{Questionnaires for thyroidectomy-related dysphagia}

Patients report different and unspecific symptoms of swallowing impairment after thyroid surgery, and swallowing symptoms after thyroidectomy are under- reported in the literature. The incidence of postoperative dysphagia varies between $5 \%$ to $58 \%$ depending on age, assessment method, and questionnaire used in various studies ${ }^{6,16,42}$. In a recently published qualitative study, Keleker et al. reported that approximately $80 \%$ of patients experience swallowing-related symptoms after thyroidectomy, and many develop compensatory strategies to manage or reduce the symptoms ${ }^{30}$. Clinicians often overlook swallowing-related symptoms, and there is no standardized diagnostic protocol for thyroidectomy-related dysphagia. Among the re- 
Table 1. Swallowing impairment questionnaires used in the reviewed studies

\begin{tabular}{|l|l|l|l|}
\hline Questionnaire: & Developed by: & $\begin{array}{l}\text { First } \\
\text { published: }\end{array}$ & $\begin{array}{l}\text { The number of reviewed studies } \\
\text { that used the questionnaire }\end{array}$ \\
\hline $\begin{array}{l}\text { Swallowing impairment score } \\
\text { index (SIS-6) }\end{array}$ & $\begin{array}{l}\text { Lombardi CP, Raffaelli M, } \\
\text { D'Alatri L, et al. }\end{array}$ & 2006 & 14 \\
\hline $\begin{array}{l}\text { Upper Aerodigestive Symptoms } \\
\text { (UADS) }\end{array}$ & $\begin{array}{l}\text { de Pedro Netto I, Fae A, } \\
\text { Vartanian JG, et al. }\end{array}$ & 2006 & 2 \\
\hline $\begin{array}{l}\text { Foreign-body sensation in the } \\
\text { throat score (FBST) }\end{array}$ & Koike Y, Ishitani Y, Nakamura K & 1988 & 1 \\
\hline $\begin{array}{l}\text { Thyroidectomy-Related Voice } \\
\text { Changes (TVQ) }\end{array}$ & $\begin{array}{l}\text { Nam IC, Bae JS, Shim MR, } \\
\text { Hwang YS, Kim MS, Sun DI. }\end{array}$ & 2012 & 1 \\
\hline $\begin{array}{l}\text { Glasgow-Edinburgh Throat Scale } \\
\text { (GTS) }\end{array}$ & $\begin{array}{l}\text { Deary IJ, Wilson JA, Harris MB, } \\
\text { MacDougall G. }\end{array}$ & 1995 & 1 \\
\hline $\begin{array}{l}\text { Swallowing quality-of-life } \\
\text { (SWAL-QOL) and } \\
\text { Swallowing quality-of-care } \\
\text { (SWAL-CARE) }\end{array}$ & $\begin{array}{l}\text { McHorney CA, Robbins J, } \\
\text { Lomax K, et al. }\end{array}$ & 2000 & 2 \\
\hline $\begin{array}{l}\text { M.D. Anderson dysphagia index } \\
\text { (MDADI) }\end{array}$ & $\begin{array}{l}\text { Chen AY, Frankowski R, } \\
\text { Bishop-Leone J, et al. }\end{array}$ & 2001. & 1 \\
\hline Thyro PRO & $\begin{array}{l}\text { McHorney CA, Robbins J, } \\
\text { Lomax K, et al. }\end{array}$ & 2000 & 1 \\
\hline
\end{tabular}

viewed studies, 8 different questionnaires were used to identify patients with swallowing difficulties after thyroid surgery, 5 of them assessed swallowing-related symptoms and 3 assessed QoL (Table 1).

The Swallowing Impairment Index (SIS-6) was the most-used questionnaire among the reviewed studies (14 studies) $)^{5,6,8,11,16-18,25,33,38,40,53,56}$. It is a specifically designed questionnaire self-evaluation that, with simple statements, addresses the spectrum of symptoms typically reported by patients. It consists of 6 statements scored within a range of 0 (without swallowing alterations) to 4 (maximum swallowing dysfunction) (Table 2) ${ }^{4}$. Among the reviewed studies, it was used for comparison of dysphagia severity before and after the surgical procedure, or determining dysphagia severity depending on the surgical method and approach, extent of surgical resection, intraoperative neuromonitoring, or intraoperative anti adherence materials. SIS-6 was also used for long-term followup. Due to quick assessment, SIS-6 data can be easily obtained in everyday clinical practice for the diagnostic purposes and follow-up.

The Upper Aerodigestive Symptoms (UADS) questionnaire was used in 2 reviewed studies. This questionnaire consists of two parts, one relating to voice symptoms and the other to swallowing symptoms ${ }^{44}$. Voice symptoms include vocal fatigue, difficulty speaking loudly or in a high pitch, hoarseness, and a low- or high-pitched voice. Swallowing symptoms include burning during deglutition, pain during deglutition, pharyngeal pain during deglutition, choking, dry throat, discomfort during deglutition, throatclearing during deglutition, scar stiffness during swallowing, a sensation of a foreign body in the pharynx, strangling during deglutition, and coughing during deglutition. Positive responses to the questionnaire were quantified according to a 4-point Likert-like scale that ranked the symptoms as not a problem, a minor problem, a moderate problem, or a major problem. The UADS questionnaire is a modified Voice Handicap Index questionnaire designed to include additional symptoms that some patients reported in previous studies, which were not included in the original VHI questionnaire ${ }^{44}$. The UADS questionnaire is still new, and further investigation is needed to determine whether and to what degree it can compare with other similar questionnaires and predict patient outcomes based on the answers given.

Other questionnaires used were the Foreign-body Sensation in the Throat Score (FBST), Thyroidecto- 
my-related Voice Changes (TVQ) and the GlasgowEdinburgh Throat Scale (GETS), which were used only once in the reviewed studies.

FBST is an 11-item, condition-specific instrument ${ }^{57}$. Each response is scored according to the magnitude of the FBST value. Each patient is asked to select one or two statements from the list that are most similar to their foreign-body sensation in the throat. The average of the values attached to the selected statements is considered the FBST value for the patient. The total score ranges from 0 (no problem perceived) to 8.2 (maximum perceived disability due to neck discomfort $)^{57}$.

The TVQ is a self-assessment tool for evaluating voice- and swallowing-related symptoms associated with thyroid surgery ${ }^{58}$. It consists of 20 statements based on the voice handicap index (VHI) and other studies on subjective symptoms related to thyroidectomy. The statements concern general voice complaints, representative symptoms related to LPR and vocal cord palsy, and swallowing-related symptoms associated with thyroidectomy. Responses to each are scored from a minimum of 0 (no voice alterations or symptoms) to a maximum of 80 (highest voice impairment and multiple vocal symptoms). If a patient presents with a questionnaire score of more than 5 , surgeons can perform laryngoscopy or stroboscopy and voice analysis to detect underlying voice disorders.

GETS uses a 10-item questionnaire (8-grade Likert scale with 0 indicating none and 7 indicating unbearable, reported by the patient) to assess the severity of throat discomfort ${ }^{59}$. The nine items in GETS can be further divided into three subgroups to represent different symptoms: dysphagia, globus sensation, pain and swelling in the throat. The total GETS score (0$70)$ is classified into four degrees which are: asymptomatic (0-2), mildly symptomatic (3-8), symptomatic (9-20), and strongly symptomatic ( $>20)$.

Only 4 studies investigated the influence of swallowing difficulties related to thyroidectomy on QoL. The swallowing quality of life (SWAL-QOL) and swallowing quality of care (SWAL-CARE) was used in 2 studies, and the MD Anderson dysphagia index (MDADI) and TyroPRO were used in one study each.

The swallowing quality of life (SWAL-QOL) and swallowing quality of care (SWAL-CARE) address 10 domains that represent swallowing impairment: swallowing burden, food selection, symptom frequency/ bother, eating duration, eating desire, fear, fatigue, sleep, communication, mental health, and social functioning ${ }^{60-62}$.

The MDADI was developed as a dysphagia-specific quality-of-life questionnaire for patients with head and neck cancer ${ }^{63}$. It consists of 20 statements in four subscales: global, emotional, functional, physical. Patients have to mark a response on a five-point scale (strongly agree, agree, no opinion, disagree, and strongly disagree) which best reflects their experience in the past week. A higher MDADI score represents better day-to-day functioning and better QoL.

ThyPRO is a validated and reliable questionnaire developed by Watt et al. in 2009, which is specifically for measuring QoL in patients with various thyroid diseases $^{64}$. The questionnaire includes 84 items, divided into 13 domains: goiter symptoms, hyperthyroid symptoms, hypothyroid symptoms, eye symptoms, tiredness, cognitive impairment, anxiety, depression, emotional susceptibility, impaired social life, impaired daily life, impaired sex life, and cosmetic complaints ${ }^{64,65}$.

\section{Instrumental diagnostic tools for thyroidectomy related dysphagia}

Instrumental diagnostic procedures help identify the mechanisms involved in swallowing impairment ${ }^{45}$. Among the reviewed studies, 9 different diagnostic tools were used to objectively verify patients with swallowing difficulties after thyroid surgery (Figure 3).

Fiberoptic laryngoscopy represents a standard diagnostic procedure that all patients scheduled for thyroid surgery should undergo prior to surgical treatment as well as postoperatively. It is primarily performed in order to identify changes in vocal fold mobility and to differentiate patients with laryngeal nerve

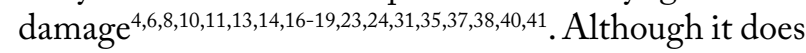
not provide information on swallowing impairment, swelling of laryngeal mucosa, especially in the posterior part of the larynx and retrocricoid area, can indirectly indicate laryngopharyngeal reflux, whereas saliva residue in the piriform sinuses or retrocricoid area can indicate dysfunction of the upper esophageal sphincter ${ }^{67}$. Stroboscopy can help identify vocal fold mobility changes, especially if a lesion of the superior laryngeal nerve is suspected, but it does not provide any information on swallowing impairments, ${ }^{4,5,10,17}$.

Videofluorography or videofluoroscopy (VFS) provides a real-time study of the oral, pharyngeal, and esophageal phase ${ }^{45,68,69}$. It is considered the gold standard for evaluation of the complete swallowing act. 


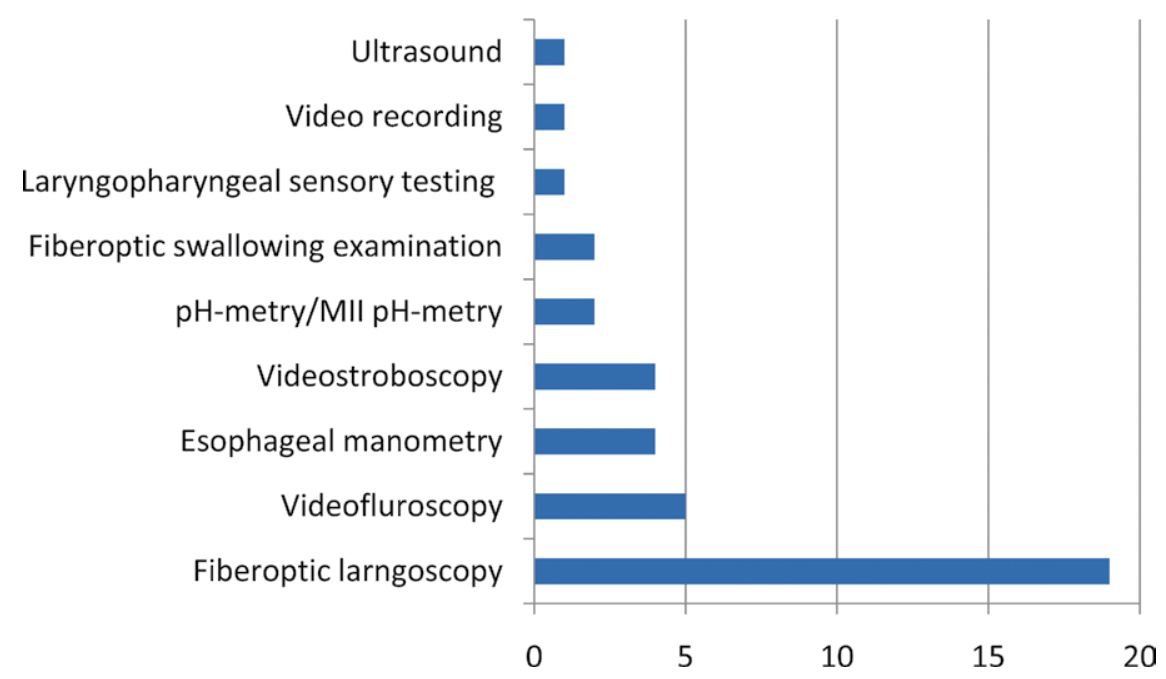

Figure 3. Number of reviewed studies using instrumental diagnostic tools.

Among the reviewed studies, 5 used VFS to verify swallowing changes. Using VFS investigators detected decreased hyoid movement, delayed barium swallowing time, hypopharyngeal bolus stasis, changes in epiglottal tilting and longer laryngeal response duration, esophageal dyskinesia, and gastroesophageal reflux ${ }^{6,13,30,38,39}$. Fiorentino et al. reported changes in cricopharyngeal muscle contraction and gastroesophageal reflux in the proximal esophagus provoked with a water siphon test ${ }^{13}$. Unfortunately, boluses tested during VFS were all a thin liquid, and swallowing examination did not include other consistencies.

Esophageal manometry identifies esophageal motility changes, especially changes in the upper esophageal sphincter (UES) and the lower esophageal sphincter (LES). High-resolution esophageal manometry (HRM) is regarded as a gold standard instrumental diagnostic tool for the identification and classification of esophageal motility disorders ${ }^{70}$. HRM uses a high-resolution catheter to transmit intraluminal pressure data that are subsequently converted into dynamic esophageal pressure topography plots ${ }^{71}$. We reviewed 3 studies that used esophageal manometry and one in which the authors used HRM. Results from all the studies were not comparable, but they all identify UES pressure decrease and incoordination in patients with swallowing difficulties prior to or after surgery $y^{6,9,20,25}$. Although HRM provides the most reliable information on esophageal motility, it is very uncomfortable for patients, as well as expensive and time-consuming.

LPR can play a significant role in thyroidectomyrelated dysphagia symptoms such as globus sensation and hoarseness, and LPR-related symptoms remain a diagnostic and therapeutic challenge. The pathophysiological mechanism of LPR is still unclear. The most commonly discussed theory is that LPR symptoms are a result of direct alteration of the pharyngeal and laryngeal mucosa by gastric fluids. Multichannel impedance monitoring in combination with $\mathrm{pH}-$ metry $(\mathrm{pH} /$ MII) and 2-channel $\mathrm{pH}$-metry are safe and reliable tools to objectively identify gastroesophageal reflux events as a source of LPR symptoms ${ }^{72}$. Only two reviewed studies used $\mathrm{pH}$ monitoring with manometry. They only confirmed a significant correlation between patients with voice symptoms and upper esophageal acid reflux $x^{6,25}$.

Endoscopic swallowing evaluation provides a direct view of the pharyngeal and laryngeal anatomical structures and a real-time 3-D study of their movement characteristics: speed, precision, and range ${ }^{73}$. Endoscopic swallowing evaluation is highly sensitive for bolus penetration to the larynx and aspiration to the trachea, it allows a good view of bolus residues, and can provide test sensation ${ }^{74-76}$. Endoscopic swallowing evaluation can be performed with different consistencies which provide better insight in swallowing difficulties that patient experience in everyday life. Two studies used endoscopic swallowing evaluation during flexible fiberoptic examination ${ }^{14,23}$. They identified penetration and aspiration of the liquid bolus in patients with laryngeal nerves lesions and bolus pooling in the piriform sinuses in a significant number of patients with thyroidectomy-related swallowing difficulties. 
Laryngopharyngeal sensory testing can be performed during endoscopic swallowing evaluation. The laryngeal adductor reflex has been previously validated as an objective and accurate clinical method of assessing laryngopharyngeal sensory capacity ${ }^{77}$. Blocks of ascending and descending air pulse stimuli are delivered through the working channel on the tip of the laryngoscope $2 \mathrm{~mm}$ from the targeted area and measured in $\mathrm{mm} \mathrm{Hg}$. When the reflex is observed, the stimulus level is recorded. There is only one group of authors that studied the laryngopharyngeal sensory discrimination test in patients before and after thyroidectomy. In testing the function of the internal branch of the superior laryngeal nerve, they showed that the mean postoperative change in thresholds was trivial and did not differ significantly from zero.

Only one group of authors used ultrasound in order to investigate long-term changes in laryngeal elevation after thyroidectomy. They concluded that laryngeal elevation in patients with swallowing difficulties was significantly impaired postoperatively and only women presented with a recovery close to baseline after 6 months. Although male patients rarely complained of swallowing impairment, they show only a small grade of recovery of laryngeal movement ${ }^{34}$.

Video recordings were only used in one review study. The authors compared dysphagia symptoms and clinical signs following gasless transaxillary endoscopic thyroidectomy versus conventional open thyroidectomy. Video recordings of swallowing movement were used to determine the contraction/relaxation (CR) ratio and evaluate adhesion, pre-operatively and 3 days and 1 month postoperatively. They concluded that the $\mathrm{CR}$ ratio increased in the open thyroidectomy group after the surgery and continued to increase during 1-month post-operation, but decreased in the gasless transaxillary endoscopic thyroidectomy group ${ }^{33}$.

\section{Limitations}

We conducted a bibliographic search using only the MEDLINE/PubMed electronic database, and no other database was included in this search.

\section{Conclusion}

Dysphagia after thyroid surgery is a common postoperative complication which, in the short- or long- term, significantly affects patient life quality. It is often overseen in patients who underwent uncomplicated thyroid surgery without nerve palsy, and those patients therefore do not receive the appropriate follow-up and therapeutic care. Considering the large number of individuals who may experience subjective thyroidectomy-related dysphagia, patients should be preoperatively and postoperatively questioned about swallowing symptoms. They should be informed about possible post-thyroidectomy-related swallowing impairment, and preoperative counselling should include education about diagnostic procedures and possible treatment options for such symptoms. We recommend the SIS-6 questionnaire for a quick assessment and SWALQOL for more detailed information concerning difficulties with swallowing and their impact on QoL after thyroid surgery. Since fiberoptic endoscopy should be performed in all patients before and after thyroid surgery as a standard diagnostic tool for upper aerodigestive system evaluation, fiberoptic swallowing evaluation can be easily obtained in patients with swallowing difficulties. However, instrumental findings usually reveal non-specific alterations of swallowing, and videofluoroscopy of swallowing and esophageal manometry should be performed if there is a need for further diagnostic investigation. In patients with suspected LPR after RSI, 24-hour MII-pH-metry should be performed as a gold standard.

\section{References}

1. Galluzzi F, Garavello W. Dysphagia following uncomplicated thyroidectomy: a systematic review. Eur Arch Otorhinolaryngol. 2019;276(10):2661-2671. doi:10.1007/s00405-01905599-y

2. Kusić Z, Prgomet D. Karcinom štitne i doštitne žljezde. In: Prgomet D. Tumori glave i vrata. Zagreb: Medicinska naklada. 2019.p. 262-73. Croatian

3. Prgomet D, Janjanin S, Bilić M, et al. A prospective observational study of 363 cases operated with three different harmonic scalpels. Eur Arch Oto-Rhino-Laryngology. 2009;266 (12):1965-1970. doi:10.1007/s00405-009-0954-3

4. Lombardi CP, Raffaelli M, D'Alatri L, et al. Voice and swallowing changes after thyroidectomy in patients without inferior laryngeal nerve injuries. Surgery. 2006;140(6):1026-1034. doi:10.1016/j.surg.2006.08.008

5. Lombardi CP, D'Alatri L, Marchese MR, et al. Prospective electromyographic evaluation of functional postthyroidectomy voice and swallowing symptoms. World J Surg. 2012;36(6): 1354-1360. doi:10.1007/s00268-012-1481-8 
6. Scerrino G, Inviati A, Di Giovanni S, et al. Esophageal motility changes after thyroidectomy; possible associations with postoperative voice and swallowing disorders: preliminary results. Otolaryngol Head Neck Surg. 2013;148(6):926-932. doi: 10.1177/0194599813482299

7. Pereira JA, Girvent M, Sancho JJ, Parada C, Sitges-Serra A. Prevalence of long-term upper aerodigestive symptoms after uncomplicated bilateral thyroidectomy. Surgery. 2003;133(3): 318-322. doi:10.1067/msy.2003.58

8. Lombardi CP, Raffaelli M, De Crea C, et al. Long-term outcome of functional post-thyroidectomy voice and swallowing symptoms. Surgery. 2009;146(6):1174-1181. doi:10.1016/j. surg.2009.09.010

9. Sorensen JR. The impact of surgery on quality of life, esophageal motility, and tracheal anatomy and airflow in patients with benign nodular goiter. Dan Med J. 2018;65(4):B5472. https:// pubmed.ncbi.nlm.nih.gov/29619937.

10. Tae K, Kim KY, Yun BR, et al. Functional voice and swallowing outcomes after robotic thyroidectomy by a gasless unilateral axillo-breast approach: comparison with open thyroidectomy. Surg Endosc. 2012;26(7):1871-1877. doi:10.1007/s00464011-2116-0

11. Kim WW, Jung JH, Lee J, et al. Comparison of the Quality of Life for Thyroid Cancer Survivors Who Had Open Versus Robotic Thyroidectomy. J Laparoendosc Adv Surg Tech A. 2016; 26(8):618-624. doi:10.1089/lap.2015.0546

12. Holler T, Anderson J. Prevalence of voice \& swallowing complaints in Pre-operative thyroidectomy patients: a prospective cohort study. J Otolaryngol Head Neck Surg. 2014;43(1):28. doi:10.1186/s40463-014-0028-4

13. Fiorentino E, Cipolla C, Graceffa G, et al. Local neck symptoms before and after thyroidectomy: a possible correlation with reflux laryngopharyngitis. Eur Arch Otorhinolaryngol. 2011;268(5):715-720. doi:10.1007/s00405-010-1394-9

14. Arakawa-Sugueno L, Ferraz AR, Morandi J, et al. Videoendoscopic Evaluation of Swallowing After Thyroidectomy: 7 and 60 Days. Dysphagia. 2015;30(5):496-505. doi:10.1007/s00455 $-015-9628-z$

15. Tomoda C, Sugino K, Tanaka T, et al. Globus Symptoms in Patients Undergoing Thyroidectomy: Relationships with Psychogenic Factors, Thyroid Disease, and Surgical Procedure. Thyroid. 2018;28(1):104-109. doi:10.1089/thy.2017.0524

16. Liu N, Chen B, Li L, Zeng Q, Lv B. Subplatysmal or subfascial approach in totally endoscopic thyroidectomy has better postoperative efficacy for voice, sensory, swallowing symptoms and cosmetic result. Cohort study. Int J Surg. 2018;60:22-27. doi:10.1016/j.ijsu.2018.10.034

17. Lombardi CP, Raffaelli M, D'alatri L, et al. Video-assisted thyroidectomy significantly reduces the risk of early postthyroidectomy voice and swallowing symptoms. World J Surg. 2008;32(5):693-700. doi:10.1007/s00268-007-9443-2

18. Romano G, Scerrino G, Profita G, et al. Terminal or truncal ligation of the inferior thyroid artery during thyroidectomy? A prospective randomized trial. Int J Surg. 2016;28 Suppl 1:S13S16. doi:10.1016/j.ijsu.2015.05.057

19. Lifante J-C, McGill J, Murry T, Aviv JE, Inabnet 3rd WB. A prospective, randomized trial of nerve monitoring of the external branch of the superior laryngeal nerve during thyroidectomy under local/regional anesthesia and IV sedation. Surgery. 2009;146(6):1167-1173. doi:10.1016/j.surg.2009.09.023

20. Sorensen JR, Markoew S, Døssing H, Hegedüs L, Bonnema SJ, Godballe C. Changes in Swallowing Symptoms and Esophageal Motility After Thyroid Surgery: A Prospective Cohort Study. World J Surg. 2018;42(4):998-1004. doi:10.1007/ s00268-017-4247-5

21. de Araújo LF, Lopes LW, Silva POC, Perrusi VJF, Farias VL de L, Azevedo EHM. Sensory symptoms in patients undergoing thyroidectomy TT - Sintomas sensoriais em pacientes submetidos à tireoidectomia. CoDAS. 2017;29(3):e20150294-e20150294. doi:10.1590/2317-1782/20172016294

22. Maung KH, Hayworth D, Nix PA, Atkin SL, England RJA. Thyroidectomy does not cause globus pattern symptoms. J Laryngol Otol. 2005;119(12):973-975. doi:10.1258/0022215 05775010760

23. Park YM, Oh KH, Cho J-G, et al. Changes in Voice- and Swallowing-Related Symptoms After Thyroidectomy: OneYear Follow-Up Study. Ann Otol Rhinol Laryngol. 2018; 127(3):171-177. doi:10.1177/0003489417751472

24. Wasserman JM, Sundaram K, Alfonso AE, Rosenfeld RM, Har-El G. Determination of the function of the internal branch of the superior laryngeal nerve after thyroidectomy. Head Neck. 2008;30(1):21-27. doi:10.1002/hed.20648

25. Scerrino G, Inviati A, Di Giovanni S, et al. Long-term esophageal motility changes after thyroidectomy: associations with aerodigestive disorders. G Chir. 2017;37(5):193-199. doi: 10.11138/gchir/2016.37.5.193

26. Dralle H. Neuromonitoring can reduce the frequency of aerodigestive tract complaints after thyroid gland operations TT - Neuromonitoring senkt die Häufigkeit von Aerodigestivtraktbeschwerden nach Schilddrüsenoperationen. Chirurg. 2012;83(11):992. doi:10.1007/s00104-012-2378-7

27. Burns P, Timon C. Thyroid pathology and the globus symptom: are they related? A two year prospective trial. J Laryngol Otol. 2007;121(3):242-245. doi:10.1017/S0022215106002465

28. Sabaretnam M, Mishra A, Chand G, et al. Assessment of swallowing function impairment in patients with benign goiters and impact of thyroidectomy: a case control study. World J Surg. 2012;36(6):1293-1299. doi:10.1007/s00268-012-1562-8

29. Greenblatt DY, Sippel R, Leverson G, Frydman J, Schaefer S, Chen $H$. Thyroid resection improves perception of swallowing function in patients with thyroid disease. World J Surg. 2009;33(2):255-260. doi:10.1007/s00268-008-9837-9

30. Krekeler BN, Wendt E, Macdonald C, et al. Patient-Reported Dysphagia After Thyroidectomy: A Qualitative Study. JAMA Otolaryngol Head Neck Surg. 2018;144(4):342-348. doi:10.1001/jamaoto.2017.3378 
31. Tedla M, Chakrabarti S, Suchankova M, Weickert MO. Voice outcomes after thyroidectomy without superior and recurrent laryngeal nerve injury: VoiSS questionnaire and GRBAS tool assessment. Eur Arch Otorhinolaryngol. 2016;273(12):45434547. doi:10.1007/s00405-016-4163-6

32. Chun B-J, Bae J-S, Lee S-H, Joo J, Kim E-S, Sun D-I. A prospective randomized controlled trial of the laryngeal mask airway versus the endotracheal intubation in the thyroid surgery: evaluation of postoperative voice, and laryngopharyngeal symptom. World J Surg. 2015;39(7):1713-1720. doi:10.1007/ s00268-015-2995-7

33. Hyun K, Byon W, Park H-J, Park Y, Park C, Yun J-S. Comparison of swallowing disorder following gasless transaxillary endoscopic thyroidectomy versus conventional open thyroidectomy. Surg Endosc. 2014;28(6):1914-1920. doi:10.1007/ s00464-013-3413-6

34. Gohrbandt AE, Aschoff A, Gohrbandt B, Keilmann A, Lang $\mathrm{H}$, Musholt TJ. Changes of Laryngeal Mobility and Symptoms Following Thyroid Surgery: 6-Month Follow-Up. World J Surg. 2016;40(3):636-643. doi:10.1007/s00268-015-3323-y

35. Lee J, Kwon IS, Bae EH, Chung WY. Comparative analysis of oncological outcomes and quality of life after robotic versus conventional open thyroidectomy with modified radical neck dissection in patients with papillary thyroid carcinoma and lateral neck node metastases. J Clin Endocrinol Metab. 2013; 98(7):2701-2708. doi:10.1210/jc.2013-1583

36. Kim DY, Kang S-W, Kim DS, et al. Preventive Effect of $\mathrm{Hu}^{-}$ man Acellular Dermal Matrix on Post-thyroidectomy Scars and Adhesions. Dermatologic Surg. 2015;41(7):812-820. doi: 10.1097/DSS.0000000000000410

37. Woo J-W, Kim SK, Park I, Choe JH, Kim J-H, Kim JS. A novel robotic surgical technique for thyroid surgery: bilateral axillary approach (BAA). Surg Endosc. 2017;31(2):667-672. doi:10.1007/s00464-016-5018-3

38. Jung SP, Kim SH, Bae SY, et al. A new subfascial approach in open thyroidectomy: efficacy for postoperative voice, sensory, and swallowing symptoms. A randomized controlled study. Ann Surg Oncol. 2013;20(12):3869-3876. doi:10.1245/ s10434-013-3163-7

39. Im I, Jun J-P, Crary MA, Carnaby GD, Hong KH. Longitudinal Kinematic Evaluation of Pharyngeal Swallowing Impairment in Thyroidectomy Patients. Dysphagia. 2019;34(2): 161-169. doi:10.1007/s00455-018-9949-9

40. Exarchos ST, Lachanas VA, Tsiouvaka S, et al. The impact of perioperative dexamethasone on swallowing impairment score after thyroidectomy: a retrospective study of 118 total thyroidectomies. Clin Otolaryngol. 2016;41(5):615-618. doi:10.1111/ coa. 12547

41. Alciato L, Rubin F, Villeneuve A, La Croix C, Bonfils P, Laccourreye $\mathrm{O}$. Thyroid tumors in the adult revealed by unilateral laryngeal paralysis TT - Tumeurs thyroïdiennes de l'adulte révélées par une paralysie laryngée unilatérale. Presse Med. 2019;48(9):e267-e271. doi:10.1016/j.lpm.2019.07.036
42. Sahli Z, Canner JK, Najjar O, et al. Association Between Age and Patient-Reported Changes in Voice and Swallowing After Thyroidectomy. Laryngoscope. 2019;129(2):519-524. doi: 10.1002/lary.27297

43. Almeida JP, Vartanian JG, Kowalski LP. Clinical predictors of quality of life in patients with initial differentiated thyroid cancers. Arch Otolaryngol Head Neck Surg. 2009;135(4): 342-346. doi:10.1001/archoto.2009.16

44. Silva ICM, Netto IDP, Vartanian JG, Kowalski LP, Angelis EC. Prevalence of Upper Aerodigestive Symptoms in Patients Who Underwent Thyroidectomy With and Without the Use of Intraoperative Laryngeal Nerve Monitoring. Thyroid. 2012; 22(8):814-819. doi:10.1089/thy.2011.0118

45. Scerrino G, Tudisca C, Bonventre S, et al. Swallowing disorders after thyroidectomy: What we know and where we are. A systematic review. Int J Surg. 2017;41 Suppl 1:S94-S102. doi: 10.1016/j.ijsu.2017.03.078

46. Barczyński M, Randolph GW, Cernea CR, et al. External branch of the superior laryngeal nerve monitoring during thyroid and parathyroid surgery: International neural monitoring study Group standards guideline statement. Laryngoscope. 2013;123(SUPPL. 4). doi:10.1002/lary.24301

47. Teymoortash A, Berger R, Lichtenberger G, Werner JA. Funktion und Dysfunktion des N. Laryngeus Superior. HNO. 2008;56(9):889-894. doi:10.1007/s00106-007-1595-8

48. Findlay JM, Mihai R. Complications of thyroid surgery. Br J Hosp Med. 2011;72(3 SUPPL.). doi:10.12968/hmed.2011.72. sup3.m44

49. Hillenbrand A, Cammerer G, Dankesreiter L, Lemke J, Henne-Bruns D. Postoperative swallowing disorder after thyroid and parathyroid resection. Pragmatic Obs Res. 2018; Volume 9:63-68. doi:10.2147/por.s172059

50. Findlay JM, Mihai R. Complications of thyroid surgery. Br J Hosp Med. 2011;72(3 SUPPL.). doi:10.12968/hmed.2011.72. sup3.m44

51. Hillenbrand A, Cammerer G, Dankesreiter L, Lemke J, Henne-Bruns D. Postoperative swallowing disorder after thyroid and parathyroid resection. Pragmatic Obs Res. 2018;9: 63-68. doi:10.2147/POR.S172059

52. Elzahaby IA, Fathi A, Abdelwahab K, et al. Endoscopic Thyroidectomy Using the Unilateral Axillo-breast Approach Versus the Modified Anterior Chest Wall Approach: A Prospective Comparative Study. Surg Laparosc Endosc Percutan Tech. 2018;28(6):366-370. doi:10.1097/SLE.0000000000000582

53. Grover G, Sadler GP, Mihai R. Morbidity after thyroid surgery: patient perspective. Laryngoscope. 2013;123(9):2319-2323. doi:10.1002/lary.23850

54. Cusimano A, Macaione I, Fiorentino E. How uncomplicated total thyroidectomy could aggravate the laryngopharyngeal reflux disease? Eur Arch Otorhinolaryngol. 2016;273(1):197202. doi:10.1007/s00405-014-3474-8

55. Zawawi F, Richardson K, Varshney R, et al. Postthyroidectomy Throat Pain and Swallowing: Do Proton Pump Inhibitors 
Make a Difference? ISRN Otolaryngol. 2013;2013:1-4. doi: 10.1155/2013/135978

56. Ryu J-H, Han S-S, Do S-H, Lee J-M, Lee S-C, Choi E-S. Effect of adjusted cuff pressure of endotracheal tube during thyroidectomy on postoperative airway complications: prospective, randomized, and controlled trial. World J Surg. 2013;37(4):786-791. doi:10.1007/s00268-013-1908-х

57. Koike Y, Ishitani Y, Nakamura K, Nakanishi R. Quantification of Foreign-body Sensation in the Throat. Pract Otol Suppl. 1988;1988:46-50. doi:10.5631/jibirinsupp11986.1988.Supplement23_46

58. Deary IJ, Wilson JA, Harris MB, Macdougall G. Globus pharyngis: Development of a symptom assessment scale.J Psychosom Res. 1995;39(2):203-213. doi:10.1016/0022-3999(94)00104-D

59. Consorti F, Mancuso R, Mingarelli V, Pretore E, Antonaci A. Frequency and severity of globus pharyngeus symptoms in patients undergoing thyroidectomy: A pre-post short term crosssectional study. BMC Surg. 2015;15(1). doi:10.1186/s12893015-0037-x

60. McHorney CA, Bricker DE, Kramer AE, et al. The SWALQOL outcomes tool for oropharyngeal dysphagia in adults: I. Conceptual foundation and item development. Dysphagia. 2000;15(3):115-121. doi:10.1007/s004550010012

61. McHorney CA, Earl Bricker D, Robbins J, Kramer AE, Rosenbek JC, Chignell KA. The SWAL-QOL outcomes tool for oropharyngeal dysphagia in adults: II. Item reduction and preliminary scaling. Dysphagia. 2000;15(3):122-133. doi: 10.1007/s004550010013

62. McHorney CA, Robbins JA, Lomax K, et al. The SWAL-QOL and SWAL-CARE outcomes tool for oropharyngeal dysphagia in adults: III. Documentation of reliability and validity. Dysphagia. 2002;17(2):97-114. doi:10.1007/s00455-001-0109-1

63. Chen AY, Frankowski R, Bishop-Leone J, et al. The Development and Validation of a Dysphagia-Specific Quality-of-Life Questionnaire for Patients With Head and Neck Cancer: The M. D. Anderson Dysphagia Inventory. Arch Otolaryngol Neck Surg. 2001;127(7):870-876. doi:10-1001/pubs.Arch Otolaryngol. Head Neck Surg.-ISSN-0886-4470-127-7-ooa00162

64. Watt T, Bjorner JB, Groenvold M, et al. Establishing construct validity for the thyroid-specific patient reported outcome measure (ThyPRO): An initial examination. Qual Life Res. 2009; 18(4):483-496. doi:10.1007/s11136-009-9460-8

65. Watt T, Hegedüs L, Groenvold M, et al. Validity and reliability of the novel thyroid-specific quality of life questionnaire, ThyPRO. Eur J Endocrinol. 2010;162(1):161-167. doi:10.1530/ EJE-09-0521
66. Araújo LF de, Lopes LW, Silva POC, Perrusi VJF, Farias VL de L, Azevedo EHM. Sensory symptoms in patients undergoing thyroidectomy TT - Sintomas sensoriais em pacientes submetidos à tireoidectomia. CoDAS. 2017;29(3):e20150294e20150294. doi:10.1590/2317-1782/20172016294

67. Kirti YK. Reflux Finding Score (RFS) a Quantitative Guide for Diagnosis and Treatment of Laryngopharyngeal Reflux. Indian J Otolaryngol Head Neck Surg. 2018;70(3):362-365. doi:10.1007/s12070-018-1350-3

68. Costa MMB. Videofluoroscopy: The gold standard exam for studying swallowing and its dysfunction. Arq Gastroenterol. 2010;47(4):327-328. doi:10.1590/S0004-28032010000400001

69.Bilic M, Kovac-Bilic L, Hodzic-Redzic S, Prgomet D. Comparison of Swallowing Act Videofluoroscopy after Open and Laser Partial Supraglottic Laryngectomy. Iran J Otorhinolaryngol. 2018;30(101):315-319.

70. Yazaki E, Woodland P, Sifrim D. Uses of Esophageal Function Testing: Dysphagia. Gastrointest Endosc Clin N Am. 2014;24 (4):643-654. doi:10.1016/j.giec.2014.06.008

71. Yadlapati R. High-resolution esophageal manometry: Interpretation in clinical practice. Curr Opin Gastroenterol. 2017; 33(4):301-309. doi:10.1097/MOG.0000000000000369

72. Bredenoord AJ. Impedance-pH monitoring: New standard for measuring gastro-oesophageal reflux. Neurogastroenterol Motil. 2008;20(5):434-439. doi: 10.1111/j.1365-2982.2008. 01131.x

73. Langmore SE, Kenneth SMA, Olsen N. Fiberoptic endoscopic examination of swallowing safety: A new procedure. Dysphagia. 1988;2(4):216-219. doi:10.1007/BF02414429

74. Fattori B, Giusti P, Mancini V, et al. Comparison between videofluoroscopy, fiberoptic endoscopy and scintigraphy for diagnosis of oro-pharyngeal dysphagia Confronto tra videofluoroscopia, endoscopia a fibre ottiche e scintigrafia per la diagnosi di disfagia oro-faringea. ACTA Otorhinolaryngol Ital. 2016;36:395-402. doi:10.14639/0392-100X-829

75. Schatz K, Olson N. Endoscopic and videofluoroscopic evaluations of swallowing and aspiration. Ann Otol Rhinol Laryngol. 1991;100(8):678-681. doi:10.1177/000348949110000815

76. Périé S, Laccourreye L, Flahault A, Hazebroucq V, Chaussade S, St Guily JL. Role of videoendoscopy in assessment of pharyngeal function in oropharyngeal dysphagia: Comparison with videofluoroscopy and manometry. Laryngoscope. 1998;108(11): 1712-1716. doi:10.1097/00005537-199811000-00022

77. Martin JH, Thomson JE, Aviv JE, et al. Laryngopharyngeal sensory discrimination testing and the laryngeal adductor reflex. Ann Otol Rhinol Laryngol. 1999;108(8):725-730. doi: 10.1177/000348949910800802 
Sažetak

\title{
TIREOIDEKTOMIJA I POREMEĆAJI GUTANJA- PREGLED LITERATUTRE
}

\author{
Ana Đanić Hadžibegović, Filip Hergešić, Ema Babić, Juraj Slipac i Ratko Prstačić
}

Kako bismo dali bolji uvid u etiologiju i učestalost komplikacija gutanja koje su posljedica tireoidektomije te prikazali dostupne dijagnostičke postupke, proveli smo bibliografsku pretragu koristeći elektroničku bazu podataka MEDLINE / PubMed. Od ukupno 218 objavljenih članaka, u recenziju su bile uključene 44 studije. Disfagija nakon operacije štitnjače uobičajena je postoperativna komplikacija koja, kratkoročno ili dugoročno, značajno utječe na kvalitetu života pacijenta. Ne postoji standardni dijagnostički protokol za oštećenje gutanja povezano s tireoidektomijom. U studijama uključenim u pregled literature korišteno je 8 upitnika i 12 instrumentalnih postupaka za dijagnosticiranje poremećaja gutanja povezanih s operacijom štitnjače. Indeks poremećaja gutanja (SIS -6) bio je najčešće korišteni upitnik. Fiberoptička endoskopija standardni je dijagnostički postupak koji se provodi prije i nakon operacije štitnjače, prvenstveno radi identifikacije promjena pokretljivosti glasnica. Iako su nalazi instrumentalnih dijagnostičkih postupaka obično nespecifični, videofluoroskopija gutanja i manometrija jednjaka daju najviše relevatnih podataka. U bolesnika s poteškoćama gutanja i sumnjom na laringofaringealni refluks potrebno je provesti 24-satnu MII pHmetriju.

Ključne riječi: tireoidektomija, poremećaji gutanja, disfagija 